\title{
Comparison of PMMA, foldable silicone and foldable acrylic hydrophobic intraocular lenses in combined phacoemulsification and trabeculectomy
}

\author{
Comparação entre lentes intra-oculares de PMMA, lentes dobráveis de silicone elentes \\ acrílicas hidrofóbicas dobrá veis em cirurgiascombinadas de facoemulsificaçãoe \\ trabeculectomia
}

Ernani Serpa Junior ${ }^{1}$

Peter K. Wishart ${ }^{2}$
Trabalho realizado no Departamento de Glaucoma da St Paul's Eye Unit, The Royal Liverpool University Hospital - Liverpool - Inglaterra.

Ex-Fellow do Departamento de Glaucoma do The Royal Liverpool University Hospital e atual médico responsável pelo Departamento de Glaucoma do Hospital Governador Celso Ramos (Hospital dos Servidores) Florianópolis (SC).

${ }^{2}$ FRCOph - Médico responsável pelo Departamento de Glaucoma do The Royal Liverpool University Hospital - Liverpool - Inglaterra.

The authors have no proprietary interest in the products described in this study.

Endereço para correspondência: Ernani Serpa Jr. - Rua Rafael Bandeira, 50/1001 - Florianópolis (SC)

CEP 88015-450

E-mail: ernani@ctoflorianopolis.com.br

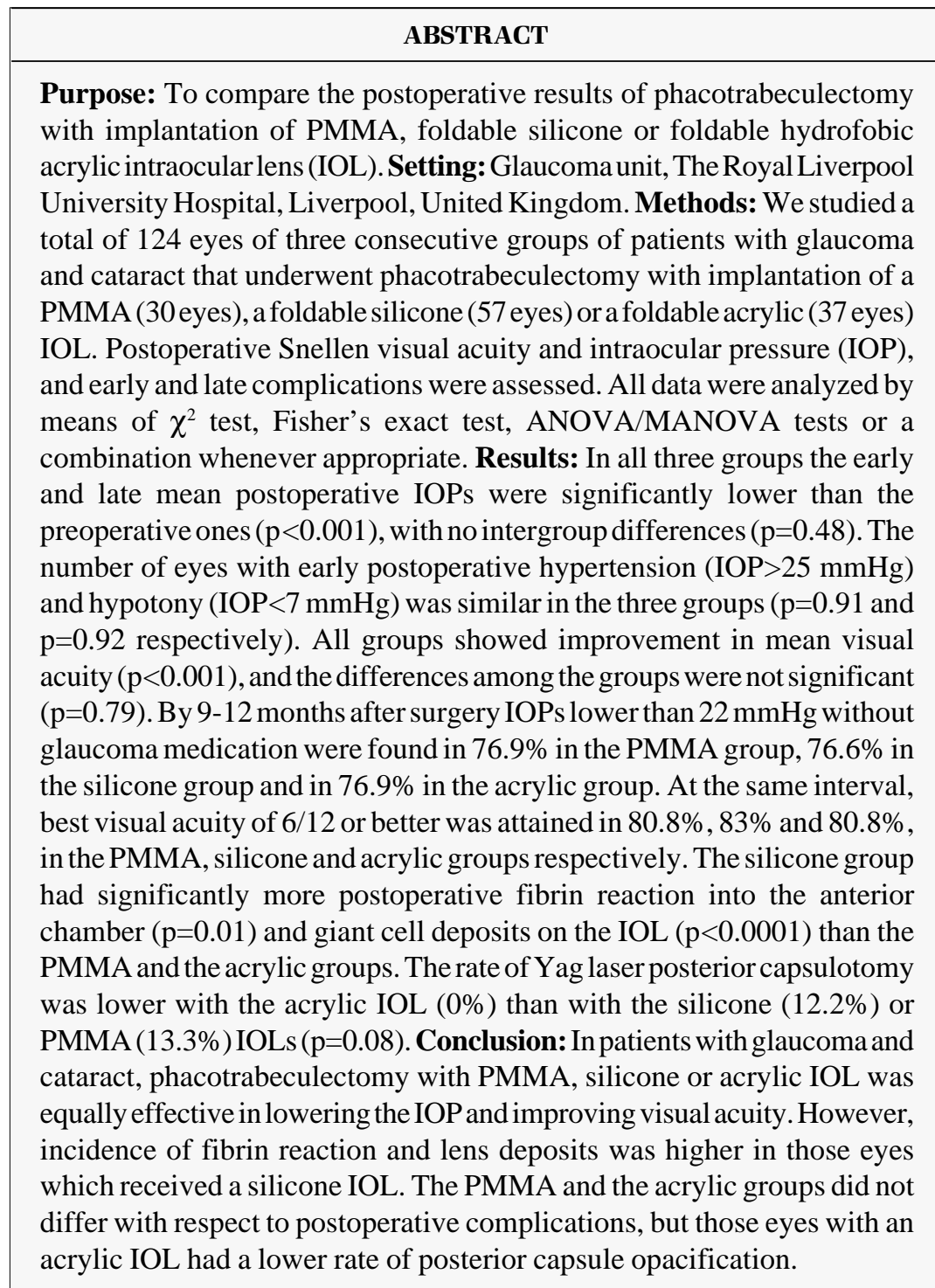

Keywords: Trabeculectomy; Phacoemulsification; Lenses, intraocular; Cataract extraction; Glaucoma/surgery 


\section{INTRODUCTION}

Since first introduced in $1968^{(1)}$, trabeculectomy has become the procedure of choice for glaucoma surgery. Phacoemulsification has also become very popular with surgeons when considering cataract removal because of its several advantages when compared to extracapsular cataract extraction. For those patients with coexisting glaucoma and cataract, combining trabeculectomy and phacoemulsification with intraocular lens (IOL) implantation has proved to be an effective approach ${ }^{(2-9)}$.

In addition to innovated surgical techniques, new foldable intraocular lenses have been developed from different materials and, as a consequence, smaller incisions can now be used for either phacoemulsification alone or combined trabeculectomy and phacoemulsification with IOL implantation, thus minimizing intraoperative risks and enhancing postoperative recovery.

We have compared the results of three consecutive groups of patients who have undergone combined trabeculectomy and phacoemulsification with implantation of IOLs of different designs and materials for each group.

Our purpose is to assess the effectiveness as well as early to long-term complications of this combined surgery when associated with each of these lenses.

\section{METHODS}

In this retrospective study, data from 124 eyes which underwent phacotrabeculectomy with IOL implantation and their results were analyzed.

Thirty eyes of 26 patients who had combined surgery from January 1993 to March 1994 received a PMMA IOL (Cilco LX $10 \mathrm{BD})$ and belong to the PMMA group. Fifty-seven eyes of 52 patients operated on from March 1994 to February 1997 received a foldable silicone lens (Chiron 32- C10 XX) and were included in the silicone group. Thirty-seven eyes of 35 patients who had their operation from March 1997 to June 1998 with a foldable acrylic lens (Alcon Acrysof Model MA 60 BM) implanted are the subjects of the acrylic group.

All patients involved in this study had preoperative examinations at The Royal Liverpool University Hospital (St. Paul's Eye Unit/Glaucoma Department) and, after written consent, were operated on by the same surgeon (P.K.W).

\section{Surgical technique}

Firstly, a fornix-based conjunctival flap was performed, followed by a triangular partial- thickness scleral flap. Secondly, with a $3.2 \mathrm{~mm}$ (for PMMA group) or a $3.0 \mathrm{~mm}$ (for silicone and acrylic groups) wide keratome, a $2.0 \mathrm{~mm}$ scleral tunnel was created and the anterior chamber entered. The next step was the creation of a side-port to allow the use of a 'microfinger' or 'mushroom manipulator' as a second instrument. Sodium hyaluronate (Healon-Pharmacia for the PMMA and silicone groups; Viscoat-Alcon for the acrylic group) was then injected into the anterior chamber and circular capsulorhexis initia- ted with a cystotome and completed with an Utrata forceps. Sphincterotomies were performed when judged necessary to create a capsulorhexis of at least $5 \mathrm{~mm}$ in diameter.

The lens was hydrodissected in order to start the phacoemulsification for which the divide-and-conquer technique was used. Cortical remnants were removed by infusion/aspiration.

Different phaco machines were used for the different groups, Universal (Alcon) for the PMMA and silicone groups and Legacy (Alcon) for the acrylic group.

Sodium hyaluronate was then injected to inflate the capsular bag and to accomodate the IOL in the bag.

The incision was then enlarged with the keratome. Incision size varied according to IOL type. Those eyes in the PMMA group received a PMMA lens with loop haptics and had their incisions enlarged to approximately $5.2 \mathrm{~mm}$. Those eyes in the silicone and acrylic groups received a foldable silicone lens with plate haptics and a foldable acrylic lens with PMMA haptics respectively, and their incisions were enlarged to approximately $3.5 \mathrm{~mm}$.

After inserting the IOL and dialing it into position, trabeculectomy was performed using a Kelly punch and the remaining sodium hyaluronate thoroughly aspirated.

The scleral flap was sutured with either 8-0 polyglactin $\left(\mathrm{Vycril}^{\oplus}\right)$ or 10-0 monofilament-nylon. The former was used for the PMMA group and the latter for the silicone and acrylic groups. The conjunctival flap was sutured with 8-0 polyglac$\operatorname{tin}\left(\mathrm{Vycril}^{\circledR}\right)$.

Atropine $1 \%$ and chloramphenicol drops were administered to the conjuctival sac and the eye was protected with a pad and shield.

All patients had atropine $1 \%$ twice a day and prednisolone $1 \%$ four times a day prescribed as postoperative medications. Both drugs were used for thirty days.

With a view to comparing these three groups, data from the following postoperative visits (intervals) were collected: first day, first month, 3-6 months, 9-12 months and last visit. Routine examinations at each visit included visual acuity assessment, biomicroscopy, applanation tonometry and fundoscopy.

For IOP and visual acuity analysis were included only those eyes of patients who attended all postoperative visits (intervals): 26 in the PMMA group, 47 in the silicone group and 26 in the acrylic group. The first day interval was not considered for Visual Acuity analysis.

For hypotony (IOP $<7 \mathrm{mmHg}$ ) and hypertension (IOP $>25 \mathrm{mmHg}$ ) on the first postoperative day and all further analysis (including patients' demographics, preoperative diagnosis, mean follow-up and postoperative complications), all eyes in each group were included.

\section{Statistical analysis}

Data were analyzed using the $\chi^{2}$ test for the contingency tables or Fisher's exact test, depending on the expected frequencies. Visual acuity measures were converted from Snellen to LogMar units in order to perform the ANOVA/MANOVA tests for repeated measures. Following these tests, another 
conversion was done and Snellen visual acuities were presented $^{(10)}$. IOP measures in each interval were also analyzed by means of ANOVA/MANOVA tests. Visual acuity and IOP measures were studied in each IOL group and the differences among the groups were analyzed.

\section{RESULTS}

All three groups were similar with respect to patients' demographics and preoperative status.

The follow-up was larger for the PMMA group than for the silicone and acrylic groups $(\mathrm{p}<0.0001)$ (Table 1$)$.

The number of eyes which had undergone previous surgery (laser iridotomy, laser trabeculoplasty or trabeculectomy) and also with history of intraoperative sphincterotomies was not significantly different among the three groups $(\mathrm{p}=0.25$ and $\mathrm{p}=0.31$, respectively). Similarly, differences in types of glaucoma were not significant $(\mathrm{p}=0.73)$ with primary open angle glaucoma (POAG) as the most common diagnosis in all groups (Table 1).

The number of preoperative glaucoma medications per eye ranged from one to three in the PMMA group, zero to three in the silicone group and zero to four in the acrylic group, with a median of two medications per eye for all groups.

There were no cases of intraoperative posterior capsule rupture in any of the groups. Intraoperative 5-fluorouracil was used in one eye of the silicone group and in four eyes of the acrylic group. Three of these eyes of the acrylic group had glaucoma secondary to uveitis.

\section{Postoperative period}

One and four eyes in the silicone and acrylic groups respectively, had either a suture released or an Argon laser suture lysis postoperatively. However, three of the four eyes in the acrylic group were excluded from IOP and visual acuity analysis because the patients did not attend all the visits as required for such analysis.

The mean postoperative IOPs were significantly lower than the mean preoperative ones at all intervals in the three groups $(\mathrm{p}<0.001)$. Nevertheless, there was no significant divergence in mean IOP values at all intervals when the groups were compared ( $\mathrm{p}=0.48)$ (Figure 1).

By 9-12 months after surgery, the percentages of eyes with IOPs lower than $22 \mathrm{mmHg}$ without any glaucoma medications were very similar in all groups $(76.9 \%, 76.6 \%$ and $76.9 \%$, for the PMMA, silicone and acrylic groups, respectively).

Analysis of the number of eyes with hypertension (IOP $>25 \mathrm{mmHg}$ ) and hypotony (IOP $<7 \mathrm{mmHg}$ ) in the first postoperative day are summarized in table 2 . Neither hypertension $(\mathrm{p}=0.91)$ nor hypotony $(\mathrm{p}=0.92)$ were significantly different in the three groups. Percentages of hypertension in the first postoperative month were also similar (zero in the PMMA group, $6.4 \%$ in the silicone group and $7.7 \%$ in the acrylic group).

The mean postoperative IOPs showed high correspondence in all groups $(\mathrm{p}=0.83)$ when comparing types of glaucoma, which, for the purposes of analysis, were separated into two groups (POAG and other types).

For all groups and at all intervals, mean postoperative

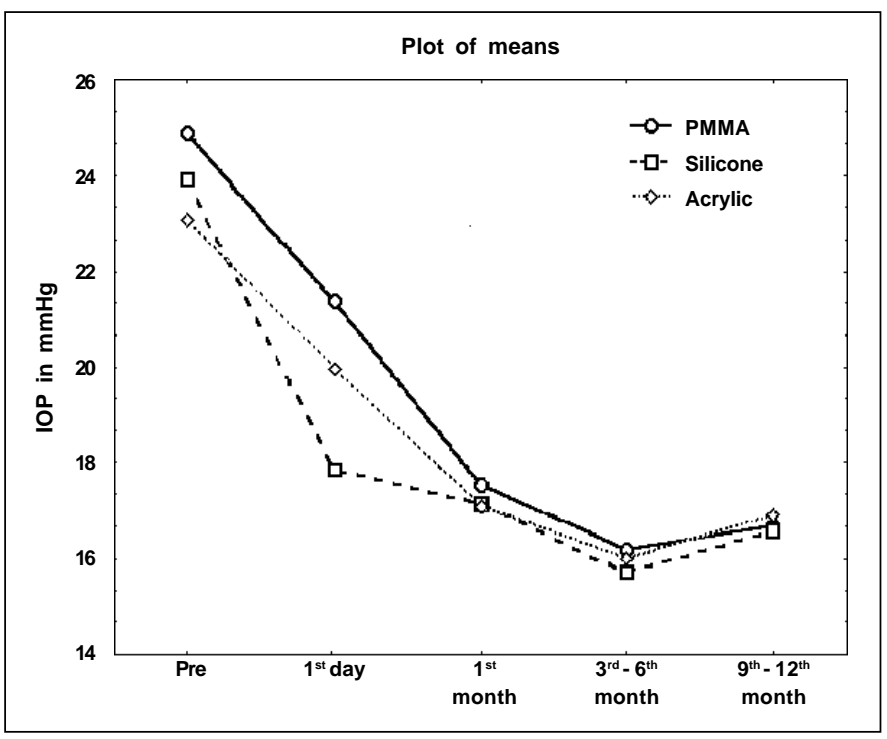

Figure 1 - Mean intraocular pressure versus time

\begin{tabular}{|c|c|c|c|c|}
\hline Characteristic & PMMA $(n=30)$ & Silicone $(n=57)$ & Acrylic $(n=37)$ & p \\
\hline Mean age (years) & $78.9 \pm 7.6$ & $78.6 \pm 6.1$ & $75.2 \pm 10.2$ & 0.08 \\
\hline Gender (men/women) & $13 / 17$ & $26 / 31$ & $18 / 19$ & 0.91 \\
\hline Mean follow-up (months) & $38.1 \pm 19.2$ & $26.2 \pm 11.5$ & $11.2 \pm 5.3$ & $<0.0001$ \\
\hline Previous surgery (number of eyes) & 11 & 12 & 12 & 0.25 \\
\hline Sphincterotomies (number of eyes) & 13 & 23 & 10 & 0.31 \\
\hline Diagnosis & & & & 0.73 \\
\hline Primary open angle glaucoma & 20 & 42 & 25 & \\
\hline Chronic angle closure glaucoma & 8 & 7 & 2 & \\
\hline Glaucoma capsulare & 2 & 7 & 5 & \\
\hline Normal tension glaucoma & 0 & 1 & 1 & \\
\hline Glaucoma secondary to uveitis & 0 & 0 & 4 & \\
\hline
\end{tabular}




\begin{tabular}{|c|c|c|c|c|}
\hline \multicolumn{3}{|c|}{ Table 2. Early postoperative intraocular pressure } & & \\
\hline Result (first day) & $\begin{array}{c}\text { PMMA }(n=30) \\
\text { Number of eyes (\%) }\end{array}$ & $\begin{array}{l}\text { Silicone }(n=57) \\
\text { Number of eyes (\%) }\end{array}$ & $\begin{array}{c}\text { Acrylic }(n=37) \\
\text { Number of eyes (\%) }\end{array}$ & $\mathbf{p}$ \\
\hline Hypertension (IOP >25mmHg) & $9(30 \%)$ & $15(26.3 \%)$ & $11(29.7 \%)$ & 0.91 \\
\hline Hypotony (IOP <7mmHg) & $3(10 \%)$ & $6(10.5 \%)$ & $3(8.1 \%)$ & 0.92 \\
\hline
\end{tabular}

visual acuities were significantly better than mean preoperative visual acuities $(p<0.001)$. In contrast, intergroup differences were not significant $(\mathrm{p}=0.79)$ (Figure 2 and Table 3). At 912 months after surgery, the percentages of eyes with visual acuities of $6 / 12$ or better were $80.8 \%, 83 \%$ and $80.8 \%$, for the PMMA, silicone and acrylic groups, respectively.

As well as for IOPs, visual acuities were not significantly different in the three groups when types of glaucoma were compared $(\mathrm{p}=0.72)$.

Early and late postoperative complications in each group are shown in table 4.

A significant larger percentage of cases of fibrin reaction was found in the silicone group (24.6\%) compared with the PMMA $(6.66 \%)$ and acrylic $(5.4 \%)$ groups $(\mathrm{p}=0.01)$.

Similarly, giant cell deposits on the anterior surface of IOLs occurred more frequently in the silicone group (24.6\%)

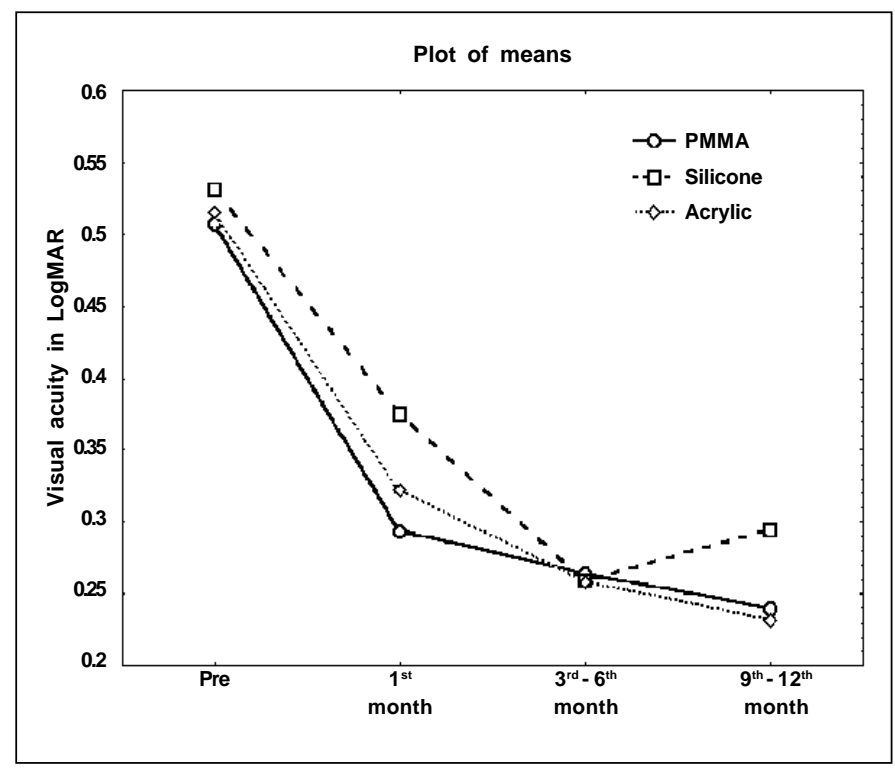

Figure 2 - Mean LogMAR visual acuity versus time

\begin{tabular}{|lcccc|}
\hline \multicolumn{5}{|c|}{ Table 3. Mean Snellen visual acuity } \\
Interval & $\begin{array}{c}\text { PMMA } \\
(\mathbf{n = 2 6})\end{array}$ & $\begin{array}{c}\text { Silicone } \\
(\mathbf{n}=\mathbf{4 7})\end{array}$ & $\begin{array}{c}\text { Acrylic } \\
(\mathbf{n}=\mathbf{2 6})\end{array}$ & $\begin{array}{c}\text { All groups } \\
(\mathbf{n}=\mathbf{9 9})\end{array}$ \\
Preoperative & $6 / 19$ & $6 / 20$ & $6 / 20$ & $6 / 20$ \\
First month & $6 / 12$ & $6 / 14$ & $6 / 13$ & $6 / 13$ \\
$3^{\text {rd }}-6^{\text {th }}$ months & $6 / 11$ & $6 / 11$ & $6 / 11$ & $6 / 11$ \\
$9^{\text {rd }}-12^{\text {th }}$ months & $6 / 10$ & $6 / 12$ & $6 / 10$ & $6 / 11$ \\
\hline
\end{tabular}

than in the PMMA (none) or acrylic (2.7\%) groups, this difference being highly significant $(\mathrm{p}<0.0001)$.

Four eyes in the silicone group coincided to have complications, fibrin reaction and lens deposits on distinct occasions.

Four eyes in the PMMA group (13.3\%) and seven eyes of the silicone group (12.2\%) developed posterior capsule opacification; however, no cases occurred in the acrylic group.

All other complications had an even distribution among the three groups.

In the PMMA group, five eyes had retinal disease (age related macular degeneration in three eyes and vein occlusion in two eyes) and three of them had their visual acuity severely affected. Retinal disease occurred in ten eyes of the silicone group (nine with age-related macular degeneration and one with vein occlusion) and, as a consequence, visual acuity was greatly impaired in two of them. Seven eyes in the acrylic group also had ocular diseases other than cataract and glaucoma (chronic uveitis in four, age related macular degeneration in two and diabetic retinopathy in one). As a result, visual acuity deeply declined in three of these eyes.

\section{DISCUSSION}

Only very few studies in the literature compare PMMA and silicone IOLs in combined phacoemulsification and glaucoma surgery. Still rarer are studies comparing foldable hydrophobic acrylic, foldable silicone and PMMA IOLs. The authors of this study did not find any related studies in the Brazilian literature.

In our study, mean follow-ups proved different in the three groups, basically because the IOLs here involved were launched on different occasions, with the PMMA lens being the first and the foldable acrylic lens the latest in the market.

Our results show that, for all groups and at all intervals, mean postoperative IOPs were significantly lower than mean preoperative IOPs, with no intergroup differences.

Similarly, the authors of two studies ${ }^{(5,8)}$ did not find between-groups difference when comparing mean early postoperative IOPs. However, their studies analyzed only groups with PMMA and foldable silicone IOLs.

In a prospective study ${ }^{(9)}$ with foldable silicone and acrylic IOLs in phacotrabeculectomies, using mitomycin C (MMC) in most of the eyes, a between-groups discrepancy was found when mean IOPs in the first postoperative month were compared $(14.1 \pm 5.0 \mathrm{mmHg}$ and $11.2 \pm 3.9 \mathrm{mmHg}$ for the acrylic and silicone groups respectively) $(\mathrm{p}=0.005)$. The authors attributed this significantly higher mean IOP found in the acrylic 


\begin{tabular}{|c|c|c|c|c|}
\hline Complication & PMMA $(n=30)$ & Silicone $(n=57)$ & Acrylic $(n=37)$ & p \\
\hline \multicolumn{5}{|l|}{ Early } \\
\hline Choroidal detachment & 2 & 3 & 5 & 0.34 \\
\hline Shallow anterior & 0 & 2 & 1 & \\
\hline Hyphema chamber & 0 & 2 & 4 & \\
\hline Cystoid macular edema & 1 & 3 & 2 & 0.90 \\
\hline Malignant glaucoma & 0 & 2 & 0 & \\
\hline Fibrin reaction & 2 & 14 & 2 & 0.01 \\
\hline \multicolumn{5}{|l|}{ Late } \\
\hline Lens deposits & 0 & 14 & 1 & $<0.0001$ \\
\hline Posterior capsule opacification & 4 & 7 & 0 & 0.08 \\
\hline Posterior synechia & 5 & 5 & 2 & 0.29 \\
\hline
\end{tabular}

group to a possible low-grade inflammation caused by the silicone IOLs or to a possible interaction among the acrylic IOLs and MMC. In addition, their results also contained a significantly higher percentage of eyes with early postoperative hypertension (IOP $>25 \mathrm{mmHg}$ ) in the acrylic group $(39.5 \%)$ compared with the silicone group (16.7\%).

A plausible theory which could explain the occurrence of higher IOPs during the very early postoperative days in eyes with acrylic IOLs has been presented ${ }^{(11)}$. According to this theory, because acrylic IOLs are more hydrophilic and also much thinner than silicone IOLs, sodium hyaluronate is more likely to be trapped in the capsular bag, under the IOL, when acrylic lenses are implanted.

Our results differ from those of Lemon et $\mathrm{al}^{(9)}$ the mean IOP on the first postoperative day was lower in the silicone group than in the other groups, but without statistical significance $(\mathrm{p}=0.48)$. From the first day onwards, IOPs were very similar in all groups. Moreover, the intergroup dissimilarities in the percentages of eyes with hypertension on the first postoperative day and in the first month did not reach statistical significance.

Emphasis must be placed on the fact that none of the eyes in our study received intraoperative MMC, and that we also implanted silicone lenses with plate haptics, therefore, different from those with PMMA haptics used by Lemon et al.

In a study with 216 eyes $^{(8)}$ phacotrabeculectomies were performed with limbal-based conjuctival flaps and eyes with PMMA IOLs were compared to those with silicone IOLs. Unlike our own findings, at 12 months after surgery, a significant difference between groups was found when percentages of eyes with IOPs lower than $22 \mathrm{mmHg}$ without glaucoma medications were compared $(78.3 \%$ in the silicone group and $57.9 \%$ in the PMMA group).

In another study ${ }^{(7)}$, ten patients were followed after combined surgery with hydrogel IOL implantation and nine of them (90\%) had unaided IOPs lower than $22 \mathrm{mmHg}$ nine months after the surgery.

Visual acuity analysis in our study started in the first postoperative month because, on this visit, our patients had their first postoperative refraction.

As seen in other studies ${ }^{(5,8-9)}$, our three groups showed a significant improvement in visual acuity postoperatively.
Some authors ${ }^{(8)}$ found that in both, PMMA and silicone groups, $87 \%$ of the eyes had visual acuity of $6 / 12$ or better twelve months after the surgery. These percentages are very similar to those found in our results.

Lemon et al, as in this present study, also converted Snellen visual acuity to LogMAR units for their analysis, and the best visual acuities that they found in the silicone and acrylic groups (20/43 and 20/35, respectively) are consistent with those in our groups.

Apart from fibrin reaction and lens deposits, all complications were evenly distributed in the three groups.

The two eyes with malignant glaucoma in the silicone group were treated with vitrectomy in the first postoperative week, and both recovered very good visual acuity and IOP.

The rates of Yag laser posterior capsulotomy were different among our groups, with $13.3 \%$ in the PMMA group, $12.3 \%$ in the silicone group, and $0 \%$ in the acrylic group. This lower rate that we found in the acrylic group could be accounted for the shorter follow-up of this group. Nevertheless, even if we consider only those cases occurring within the first eleven postoperative months, which is the mean follow-up of the acrylic group, the Yag laser rates are still higher in the PMMA and silicone groups than in the acrylic group (10\%, $7 \%$ and $0 \%$ respectively). Corroborating our results, a recent randomized study ${ }^{(12)}$ assessed the effect of PMMA, silicone and acrylic IOLs on posterior capsule opacification three years after extracapsular cataract extraction using a digital imaging system. Having the same follow-up for the three groups, the authors also found a lower rate for the acrylic group $(0 \%)$ compared to the silicone $(14 \%)$ and the PMMA (26\%) groups.

In our study, occurrence of posterior synechia was also similar in the three groups. Interestingly, four of the five cases occurring in the silicone group, and also four of the five cases found in the PMMA group had undergone intraoperative sphincterotomies.

One of the five eyes in the silicone group had a severe contraction and almost closure of the circular capsulorhexis. As a consequence, surgical anterior capsulotomy was necessary because the patient was not cooperative enough to undergo Yag laser capsulotomy. 
In a case report ${ }^{(13)}$, a very similar complication was presented, with a total anterior capsule closure two months after a phacoemulsification with a silicone IOL implantation. The authors attributed this complication to weakened zonules due to the advanced age of their patient. Another author ${ }^{(14)}$, in his letter, also attributes this complication to weakened zonules particularly as a result of pseudoexfoliation syndrome.

The patient with this complication in our study was 82 years old and had primary open angle glaucoma.

Fibrin reaction in the anterior chamber and the presence of giant cell deposits on IOLs were the two most common complications present in our study.

Fibrin reaction was found in fourteen eyes (24.6\%) in the silicone group, significantly more than in the PMMA and acrylic groups. Six of these eyes (42.9\%) had fibrin reaction on the first postoperative day; in thirteen eyes (92.9\%) it occurred within the first postoperative week. Only one eye $(7.1 \%)$ had fibrin reaction after the first week.

In the silicone group we found a strong association between intraoperative sphicterotomies and postoperative fibrin reaction $(\mathrm{p}=0.02)$. Eight out of fourteen eyes $(57.1 \%)$ with fibrin reaction had intraoperative sphincterotomies. Considering that all three groups had similar numbers of eyes with sphicterotomies and, consequently, the same surgical trauma, it is our impression that the presence of the silicone IOLs played a very important role in causing this complication, especially when associated with intraoperative sphincterotomies. In twelve of the fourteen eyes, the fibrin reaction subsided after a few days without any sequelae. One eye developed a pupillary membrane all over the anterior surface of the IOL and needed Yag laser therapy; the remaining eye developed posterior synechia. A study with rabbit models ${ }^{(15)}$, also reported more pronounced fibrin reaction in eyes with silicone IOL. In contrast, other authors ${ }^{(9)}$ did not mention the occurrence of anterior chamber fibrin reaction or lens deposits in any of the IOL groups. Unlike the results found in the literature ${ }^{(16)}$, we did not find any association between early postoperative hypotony and fibrin effusion into the anterior chamber. Only $14.3 \%$ of the eyes with fibrin reaction had postoperative hypotony.

In our results, lens deposits also proved to be more frequent in the silicone group, having occurred in fourteen eyes (24.6\%). In eight of them $(57.1 \%)$, lens deposits occurred between the second and the sixth postoperative months. In thirteen eyes $(92.9 \%)$ they occurred within the first postoperative year.

In a report ${ }^{(17)}$ on nine eyes with pigmented cellular membranes on IOLs, eight had previous phacotrabeculectomy with silicone IOL inplantation (models SI 18 NGB or SI $26 \mathrm{NB}$, AMO). In all cases, lens deposits appeared postoperatively between ten and twenty weeks, therefore, earlier than those presented in our study. The authors observed a good response to the use of topical $1 \%$ prednisolone. Nevertheless, all eyes had recurrent deposits when topical steroids were tapered. Recurrences also happened in four eyes after Yag laser treatment.

We treated six eyes with the same topical steroid medication, two eyes of which had recurrent deposits. Eight eyes did not receive treatment and, in two of them, deposits subsided spontaneously. In the other six untreated eyes the deposits persisted.

We find it difficult to explain the origin of these deposits. Taking into consideration the fact that preoperative glaucoma medications, risk factors of increased inflammatory response and surgical trauma were similar in all three studied groups we conclude that silicone IOLs play a major role in the origin of these deposits.

A possible cause for these deposits could be mechanical detachment of iris pigment epithelial cells (melanocytes) with pigment dispersion ${ }^{(15)}$, in association with some inflammatory response of the eye to the presence of silicone IOLs. The fact that most of these deposits subside with the use of strong topical steroids and recur when they are tapered reinforces the idea of inflammation as an important factor in the etiology of lens deposits.

The different surgical materials and phaco machines used in the three groups are widely used nowadays and in the authors' opinion did not influence postoperative complications and visual outcome.

On balance, we do not recommend the use of silicone IOLs with plate haptics in phacotrabeculectomies, and particularly in those eyes for which mechanical pupillary enlargement is necessary because, as shown in this study, these IOLs are associated with more postoperative complications, such as pigment deposits on the IOL and fibrin reaction into the anterior chamber. We advise the use of either PMMA or foldable hydrophobic acrylic IOLs in phacotrabeculectomies. Foldable acrylic IOLs have the advantage of requiring smaller incisions with possibly less induced postoperative astigmatism.

Further studies are needed to confirm the reduced incidence of posterior capsule opacification in eyes which undergo phacotrabeculectomy with foldable acrylic IOL implantation.

\section{ACKNOWLEDGEMENTS}

We are grateful to Dr. Augusto Paranhos Junior for his valuable help with the statistical analysis and to Mrs Debbie Woodworth from the medical records office for her solicitude during the data collection.

\section{RESUMO}

Objetivo: Comparar os resultados pós-operatórios de facotrabeculectomias com implante de lentes intra-oculares de PMMA, dobráveis de silicone e acrílicas hidrofóbicas dobráveis. Métodos: Estudo comparativo retrospectivo, realizado no Departamento de Glaucoma da "St. Paul's Eye Unit - The Royal Liverpool University Hospital”, em Liverpool, Inglaterra, onde foram estudados um total de 124 olhos de três grupos consecutivos de pacientes com glaucoma e catarata que foram submetidos à cirurgia de facotrabeculectomia com implante de lentes intra-oculares (LIO) de PMMA (30 olhos), dobráveis de silicone (57 olhos) e acrílicas hidrofóbicas dobráveis (37 olhos). Foram 
registradas a visão e pressão intra-ocular (PIO) pré e pósoperatória, assim como as complicações pós-operatórias precoces e tardias. Todos os dados foram analisados utilizando-se o teste $\chi^{2}$, teste exato de Fisher, teste de ANOVA/MANOVA ou uma combinação deles quando necessário. Resultados: Nos três grupos as PIOs pós-operatórias precoces e tardias foram significativamente inferiores às PIOs pré-operatórias $(\mathrm{p}<0,001)$, sem diferença estatística entre os grupos $(\mathrm{p}=0,48)$. O número de olhos com hipertensão (PIO $>25 \mathrm{mmHg}$ ) e hipotonia (PIO $<7 \mathrm{mmHg}$ ) pós-operatórias precoces foi semelhante nos três grupos ( $\mathrm{p}=0,91 \mathrm{e} \mathrm{p}=0,92$ respectivamente). Os três grupos mostraram melhora na acuidade visual média $(\mathrm{p}<0,001)$ e as diferenças entre os grupos não foram significativas $(p=0,79)$. Entre o $9^{0}$ e $12^{\circ}$ mês pós-operatório $76,9 \%$ dos pacientes com LIO de PMMA tinham PIOs inferiores a $22 \mathrm{mmHg}$ sem o uso de medicações hipotensoras, contra 76,6\% no grupo com LIOs de silicone e 76,9\% no grupo das LIOs acrílicas. No mesmo período, acuidade visual de 20/40 ou melhor foi alcançada por $80,8 \%, 83 \%$ e 80,8\% dos pacientes com LIOs de PMMA, silicone e acrílico, respectivamente. Olhos com LIO de silicone tiveram reação pós-operatória de fibrina na câmara anterior $(\mathrm{p}=0,01)$ e depósitos de células gigantes na LIO $(\mathrm{p}<0,0001)$ significativamente maiores do que olhos com LIO de PMMA ou acrílicas. Capsulotomia pós-operatória com Yag laser foi necessária em 13,3\% dos olhos com LIO de PMMA, 12,2\% no grupo com silicone e $0 \%$ no grupo com LIOs acrílicas $(p=0,08)$. Conclusão: Facotrabeculectomia com implante de LIO de PMMA, silicone e acrílico hidrofóbico foi igualmente efetiva na redução da PIO e melhora da acuidade visual em pacientes com glaucoma e catarata. Entretanto, a incidência de reação de fibrina na câmara anterior e o acúmulo de depósitos sobre a LIO foi maior nos olhos que receberam LIOs de silicone. Nos grupos com LIOs de PMMA e acrílico hidrofóbico não houve diferenças no que concerne a complicações pós-operatórias, no entanto, este segundo grupo teve menor incidência de opacificação de cápsula posterior.

Descritores: Trabeculectomia; Facoemulsificação; Lentes intra-oculares; Extração de catarata; Glaucoma/cirurgia

\section{REFERENCES}

1. Cairns JE. Trabeculectomy. Preliminary report of a new method. Am J Ophthalmol. 1968;66(4):673-9.

2. Kosmin AS, Wishart PK, Ridges PJ. Long-term intraocular pressure control after cataract extraction with trabeculectomy: phacomemulsification versus extracapsular technique. J Cataract Refract Surg. 1998;24(2):249-55.

3. Mamalis N, Lohner S, Rand AN, Crandall AS. Combined phacoemulsification, intraocular lens implantation, and trabeculectomy. J Cataract Refract Surg. 1996;22(4):467-73.

4. Parker JS, Gollamudi S, John G, Stark WJ. Combined trabeculectomy, cataract extraction, and foldable lens implantation. J Cataract Refract Surg. 1992; 18(6):582-5.

5. Ashore MJ, Shin DH, Hughes BA, Kim C. Comparative study of PMMA versus silicone IOL through small incision in glaucoma triple procedure. Invest Ophthalmol Vis Sci. 1996;37(suppl):51.

6. Kosmin AS, Wishart PK, Ridges PJ. Silicone versus poly (methylmethacrylate) lenses in combined phacoemulsification and trabeculectomy. J Cataract Refract Surg. 1997;23(1):97-105.

7. Allan BD, Barrett GD. Combined small incision phacoemulsification and trabeculectomy. J Cataract Refract Surg. 1993;19(1):97-102.

8. Lyle WA, Jin JC. Comparison of a 3-and 6-mm incision in combined phacoemulsification and trabeculectomy. Am J Ophthalmol. 1991;111(2):189-96.

9. Lemon LC, Shin DH, Song MS, Lee JH, Bendell RE, Juzych MS, Hughes BA. Comparative study of silicone versus acrylic foldable lens implantation in primary glaucoma triple procedure. Ophthalmology. 1997;104(10):1708-13.

10. Holladay JT. Proper method for calculating average visual acuity. J Refract Surg. 1997;13(4):388-91.

11. Safran SG. Silicone versus acrylic lenses. Ophthalmology. 1998;105(7):1125-6.

12. Hollick EJ, Spalton DJ, Ursell PG, Pande MV, Barman SA, Boyce JF, Tilling K. The effect of polymethylmethacrylate, silicone, and polyacrylic intraocular lenses on posterior capsular opacification 3 years after cataract surgery. Ophthalmology. 1999;106(1):49-54; discussion 54-5.

13. Martinez Toldos JJ, Artola Roig A, Chipont Benabent E. Total anterior capsule closure after silicone intraocular lens implantation. J Cataract Refract Surg. 1996;22(2):269-71.

14. Davison JA. Inflammatory sequelae with silicone-polypropylene IOLs. J Cataract Refract Surg. 1992;18(4):421-2.

15. Kulnig W, Menapace R, Skorpik C, Juchem M. Tissue reaction after silicone and poly (methyl methacrylate) intraocular lens implantation: a light and electron microscopy study in a rabbit model. J Cataract Refract Surg. 1989;15(5): 510-8.

16. Wedrich A, Menapace R, Radax U, Papapanos P, Amon M. Combined smallincision cataract surgery and trabeculectomy - technique and results. Int Ophthalmol. 1992;16(4-5):409-14.

17. Carlson DW, Barad JP, Parsons MR. Reduced vision secondary to pigmented cellular membranes on silicone intraocular lenses. Am J Ophthalmol. 1995; 120(4):462-70.

\section{Nos artigios enviados para publicação, o nome dos autores e suas afiliações devem estar completos. Isso facilitará a indexação e os links com as bases de dados e o CV Lates.}

